\title{
VAN DIE REDAKTEUR
}

In hierdie uitgawe van die Nederduitse Teologiese Tydskrif (NGTT) word 22 akademiese artikels aangebied. 'n Aantal van die artikels tree teologies in gesprek met belangrike temas wat tans in die brandpunt van publieke diskoers in SuidAfrika staan. Nico Koopman se artikel, byvoorbeeld, fokus op die moontlike rol wat teologie ten opsigte van die diskoers oor demokrasie in Suid-Afrika kan speel (in 2014 is 20 jaar van inklusiewe demokrasie in Suid-Afrika herdenk), terwyl Nadine Bowers-Du Toit se artikel weer aansluit by die diskoers oor armoede-verligting. 'n Hele aantal van die artikels in hierdie uitgawe fokus op Bybelinterpretasie (kyk na die artikels van Claassens, Cornelius, Hunt, Nel, Pistorius, Scharneck, Snyman en Van der Walt). 'n Ander aantal artikels bied weer navorsing aan oor temas, kerke en kerkordes wat met die gereformeerde tradisie geassosieer word (kyk byvoorbeeld na die artikels van Leder, Kruger \& Van der Merwe, en Strauss).

Hierdie uitgawe sluit ook twee uitgebreide resensie-artikels in. Ernst Conradie tree krities in gesprek met twee belangrike onlangse publikasie in die veld van ekoteologie, te wete die boeke van Larry Rasmussen en Cynthia Moe-Lobeda, en gee ook aandag aan die ontvangs van hierdie Lutheraanse stemme in 'n Suid-Afrikaanse konteks. Ryan McGraw se resensie-artikel bied weer 'n akademiese evaluering van die Ashgate Research Companion to John Owen's Theology. Twee korter resensies van publikasies van die bekende teoloë Jürgen Moltmann en NT Wright word ook in hierdie uitgawe ingesluit.

Robert Vosloo (redakteur)

Fakulteit Teologie, Universiteit Stellenbosch 


\section{FROM THE EDITOR}

This edition of the Dutch Reformed Theological Journal includes 22 academic articles. Several of the articles engage with topics that are currently at the heart of public discourse in South Africa. Nico Koopman's article, for instance, focuses on the possible role of theology with regard to the discourse on democracy in South Africa (in 2014 we commemorated 20 years of inclusive democracy in South Africa), while the article of Nadine Bowers-Du Toit deals with the discourse on poverty relief. A large number of articles in this edition focus directly or indirectly on Bible interpretation (see the articles of Claassens, Cornelius, Hunt, Nel, Pistorius, Scharneck, Snyman en Van der Walt). A number of articles also deal with themes, churches and church orders associated with the Reformed tradition (see, for instance, the articles by Leder, Kruger \& Van der Merwe, and Strauss).

We also include two review articles in this edition. In his article Ernst Conradie enters into conversation with two important recent publications on eco-theology by Larry Rasmussen and Cynthia Moe-Lobeda respectively, also attending in the process to the reception of these Lutheran voices in a South African context. Ryan McGraw's review article discusses the Ashgate Research Companion to John Owen's Theology. We also include two shorter reviews of recent publications by the wellknown and influential theologians Jürgen Moltmann and NT Wright.

Robert Vosloo (editor)

Faculty of Theology, Stellenbosch University 